\title{
Monolingual ideologies confronting multilingual realities. Finnish teachers' beliefs about linguistic diversity
}

\begin{abstract}
This study examined Finnish teachers' $(\mathrm{N}=820)$ beliefs related to multilingualism and teaching multilingual Finnish language learners. Teachers' beliefs were mainly positive. However, home languages were not always considered as learning resources. Three categories of multilingual ideologies were expressed: advocacy for, allowance and denial of multilingualism in the classroom. Factors influencing the teachers' beliefs were experience in teaching migrants, teaching area, training in linguistically responsive teaching and language awareness. The results indicate a need for professional development for all teachers to promote a move away from maintaining monolingualism to advocating for multilingualism to better reflect the realities of the classrooms.
\end{abstract}

Keywords: Multilingualism, translanguaging, linguistically responsive teaching, beliefs

\section{INTRODUCTION}

Increasing migration around the globe in the $21^{\text {st }}$ century has led to multilingual students in more and more classrooms. Most often, the language of instruction is solely the dominant language of the country, not the students' home languages. In order to teach content well in a multilingual context, every teacher has to ensure that all students can benefit from their instruction which places increasing demands on both teachers and students. However, in many countries, for example in Canada, "students' diverse linguistic capital is rarely framed or tapped into as valuable forms of literacy" (Taylor, Bernhard, Garg \& Cummins, 2008, p. 270). Ignoring the students' home languages often leads to poorer academic achievement (Menken \& Kleyn, 2010), and thus, for example, the European Commission recommends that its member states develop language awareness and multilingual pedagogies, i.e. linguistically responsive teaching in schools (European Commission, 2018).

Becoming a linguistically and culturally responsive teacher means understanding the role that language and culture have in students' learning. This is recognized in the current Finnish core curriculum, which for example calls for all teachers to have linguistic awareness and to use students' whole linguistic repertoire as a resource for learning (National Agency for Education, 2014; National Agency for Education 2015). The purpose is to help students value different languages and cultures and advocate for multilingualism in its broadest possibilities. The curriculum also advocates for the use of multiple languages side by side. However, different languages have different status in the Finnish school context, and especially the languages of 
migrant students are not always seen as valuable as, for example, the foreign languages studied at the schools. This can affect students' motivation to use and develop their languages. (Tarnanen, Kauppinen \& Ylämäki, 2017.) Other research suggests that when all languages are seen as valuable resources for literacy and learning, it affirms multilingual students' identity, strengthens their feeling of belonging in the school community, and engages them in literacy practices more actively (Cummins et al., 2005; Taylor et al., 2008).

The World Economic Forum (Chan, 2016) reported on the most influential languages in 2015, and those predicted to be the most influential in 2050. Russian and Arabic are among the top ten languages for both periods, both of which are among the most spoken foreign languages in Finland (Hämäläinen, 2017). This contrasts with public perceptions. According to a recent report by the Finnish Ministry of Education and Culture about language resources in Finland, the perception of economic life is that Russian is not spoken in Finland (Pyykkö, 2017). This failure to see that there are many migrants who speak this language vital to Finnish economic interests thus undervalues the possibility of using native speakers as resources in the economy, not to mention how it affects the identities of the speakers of different languages. As Delavan and others argue (2017, p. 87): “A comprehensive resource perspective would acknowledge a language's social, racial, cultural, political, economic, intellectual, and identity contributions, not just its economic benefits."

The same report suggests that the society needs to foster positive attitudes towards multilingualism in order to defend against increasingly negative attitudes towards migrants. In Finland, all language groups have a legal right to maintain and develop their own languages. Moreover, the new core curriculum (National Agency of Education, 2014) mandates that different languages should be used side by side in the classroom as students seek to master subject area knowledge. However, as people may use different languages at home, school or work, they are often unaware of the underlying ideologies that guide the choices they make in their language use (Lilja, Luukka \& Latomaa, 2017). Formal textual practices at school are still mainly monolingual, while students' home languages are used mainly during informal situations, usually outside the the school context (Tarnanen, et al., 2017; Taylor, et al., 2008). These monolingual practices do not meet the multilingual realities of modern classrooms. To the contrary, they strengthen monolingual ideologies and tend to identify acceptable and unacceptable languages for multilingualism. If migrant students' home languages are not seen as resources for learning, their prior knowledge may also be neglected. (Blommaert, Creve \& Villaert, 2006.) According to Taylor and others (2008), all languages and cultures should be considered as assets to the society as a whole in terms of enriched intercultural communication. This then can lead to a more peaceful society and affirm and build the identities of diverse students. 
The ways different languages are viewed in the school context are related to the attitudes and beliefs that teachers have about multilingualism. James' (1913) suggestion that beliefs influence actions and vice versa, is still relevant today. Teachers' beliefs are affected by previous schooling and professional studies, their working context, curriculum, and collegial interactions (Borg, 2006; Richards, Tung \& Ng, 1992; Voet \& DeWever, 2016), as well as language policies and the attitudes and beliefs of the general public. According to Barcelos (2003), beliefs influence the perceptions teachers have about teaching and learning, and thus affect their choices of classroom activities. Further, beliefs and values about social reality construct ideologies that influence our understanding of the world and guide our actions (Althusser, 1976), and teachers' ideological beliefs are related to the social identities of their students (Fitch, 2003). As Delawan and others argue (2017), also language policy orientations can be seen as particular ideological stances.

In the Finnish context, Tarnanen, Kauppinen \& Ylämäki (2017) found that along with curricula and learning materials, teachers' ideologies influence the selection of texts and languages used in the learning context. Therefore, obtaining information about teachers' ideologies about multilingualism and teaching multilingual Finnish language learners can be valuable for understanding teachers' pedagogical ideologies in multilingual classrooms. The data presented in this article are based on the beliefs and ideologies of Finnish teachers $(\mathrm{N}=820)$ regarding migrant Finnish language learners' use of home languages as learning resources. The study is a part of a larger project focusing on Finnish teachers' beliefs and practices related to culturally and linguistically responsive pedagogy.

\section{1 Linguistically and culturally responsive teaching}

Linguistically and culturally responsive teaching recognizes that every student's languages, cultures, identities and prior knowledge must be taken into account in instruction (Ladson-Billings, 1995). Culturally responsive teaching is "a pedagogy that empowers students intellectually, socially, emotionally, and politically by using cultural referents to impart knowledge, skills, and attitudes." (Ladson-Billings, 1994, pp 16-17). Further, it connects students' cultural knowledge, prior experiences, and performance styles to academic knowledge and intellectual tools in ways that legitimize what students already know (Gay, 2002). Because schools are sites for students' identity development, it is important to create classroom settings, where all students have a sense of belonging. It is also crucial to recognize and affirm students' home cultures, practices and identities, as well as to develop them in the school context (Paris, 2012). It is essential to understand that culture is always socially constructed and learned, and it is influenced by the contextual circumstances (Valdiviezo \& Nieto, 2017). 
Linguistically responsive teaching includes understanding that language, culture, and identity are intertwined, as noted by Lucas and Villegas $(2011 ; 2013)$. Further, they suggest that linguistically responsive teachers value linguistic diversity and advocate for multilingual students' language learning. Moreover, linguistically responsive teachers view students' multilingualism as a resource and promote students' abilities to draw on all of their linguistic resources for learning content. (Lucas \& Villegas, 2011; Lucas \& Villegas, 2013.)

Culturally and linguistically responsive education is every child's right (Valdiviezo \& Nieto, 2017). Skutnabb-Kangas (2008) defines linguistic human rights as inviolable basic rights that everyone possesses. However, in the education system, according to Skutnabb-Kangas (2008) and Dunbar (2010), linguistic diversity is very easily suppressed. Linguistic human rights in education are realized through linguistically responsive teaching only when the students are able to learn through the language of schooling, and also to learn their own languages (Skutnabb-Kangas, 2017).

According to García \& Kleyn (2012), to make linguistically and culturally responsive pedagogy a part of teachers' knowledge and skills, teacher education should include the following topics: understanding multilingual students and their families, knowledge of language and multilingualism, and understanding how to implement multilingual pedagogies. Moreover, it is important to develop the future teachers' cultural skills in various ways. Overall, it is vital that preservice teachers have possibilities to experience working with multilingual students (Edwards, 2017).

Although language and culture are intertwined, the focus of this paper is mainly on language perspectives while culturally responsive teaching is the topic of other sub-studies in the project. The analysis in the present study is tied to the renewed Finnish core curriculum, where linguistically responsive teaching has a significant role in pedagogy within the Finnish school system.

\subsection{Importance of home languages}

Research from multiple settings over the past several decades points to the significant role students' home languages play in their learning of other languages and subjects at school (Cummins, 1979, 2007; García, 1991; Goldenberg 2008; Ovando \& Combs, 2011; Slavin \& Cheung, 2005). X., X. and Author 4 (2011) suggest that "[t]he primary language, developed in the context of social interaction, is fundamental to the thinking, learning, and identity of every individual" (p. 12). That is, students' primary language is one of their principal tools for learning. While this is a basic educational concept, it is often a difficult one for people to accept and act on when it comes to linguistically diverse students. There are, however, a number of studies indicating that multilingualism has positive cognitive effects resulting in positive educational outcomes (see e.g. Cummins, 2000; Collier \& Thomas, 2007; Mehmedbegovic \& Bak, 2017). Previous research also 
shows that learning content in multiple languages does not lead to negative learning results (Antón et al., 2016).

Proficiency in first and additional languages interact with one another (Author 3, 2011; Cummins, 1979; Genesee, 1994), and the development of additional languages can benefit from, and build on, what students know and learn in their primary language. For this reason, teachers should create educational environments that allow students to develop all of their languages in the most effective and beneficial ways possible, recognizing that students in any classroom will represent a range of levels of proficiency. As X., X. and Author 4 assert, "[a]s students move from first language to second language, the task involves not simply learning new vocabulary, but rather a whole new system, expressing their knowledge and understanding" (p. 13). Moreover, as Cummins and others (2005, p. 38) put it, "pre-existing knowledge for - - language learners is encoded in their home languages", and thus, teaching should foster "transfer of concepts and skills" from students' home languages to the language of school. However, if students are made to wait to develop new school-based concepts and skills until they have enough of the language of schooling, they are blocked from using their available cognitive tools to their full potential.

According to García and Hesson (2015, p. 221), monolingual practices lead to "high rates of academic failure" in language-minoritized learners. Instead, multilingual learners' whole linguistic repertoire should be viewed as a valuable resource for learning, and teaching should be built on it (Cummins, Cohen \& Giampapa, 2006). Allowing students to make choices about which language to use, can also build and affirm their identities (Cummins et al., 2005; Tarnanen, et al., 2017). Moreover, looking only at students' additional language proficiency will give a distorted picture of their knowledge and skills. Teaching without regard to students' home language knowledge can limit expectations and students' ability to benefit from the instruction (Thomas \& Collier, 2002).

In the past decade, the field of language acquisition has taken what May (2013) refers to as a “multilingual turn.” In contrast to earlier views that separated learners' linguistic repertoire into first, second, or additional languages, a multilingual perspective examines language acquisition and development from a more holistic perspective and seeks to understand how learners' languages interact with and support each other. Chances for success increase when teachers actively engage students' home languages as a part of the learning processes and teach them how to transfer concepts and skills from one language to another (Author 2, 2011; Cummins et al., 2006). By raising multilingual learners' awareness of how their languages can work together, teachers can send a significant message to students about the importance of all languages as languages for learning. 


\subsection{Supporting students' multiple linguistic repertoires}

Linguistically responsive teaching that takes students' whole linguistic repertoire into account challenges language policies that put languages in hierarchical order, discriminate against students and their languages, and view multilingualism as a deficit (Lilja, Luukka, Latomaa, 2017). Many researchers and educators (Beeman \& Urow, 2012; Escamilla, et al., 2013; García \& Wei, 2014) recommend that teachers use various multilingual practices in their classrooms. In the 2000s', the term translanguaging has emerged in education contexts to promote bilingualism as a sustainable community resource rather than a transition to a majority language (MacSwan 2017, 167). García and others have taken this idea even further, stating that discrete languages do not exist (García \& Otheguy 2014), but that bilingual's languages are a unified system (Canagarajah 2011). Within this view on language, bi-/multilingualism is not seen as a deficit but as a resource. García \& Hesson (2015) and García, Ibarra-Johnson and Seltzer (2015) refer to teaching within a translanguaging framework. They suggest that translanguaging is part of the practice of bilingual (or multilingual) persons who use their whole linguistic repertoire for communication purposes. In a classroom that holds this view, students are able to use all their linguistic resources for all types of learning, including critical thinking and analyzing or producing texts. The role of teachers, then, is to build on all of the student's knowledge and skills in and out of the classroom regardless of the formal language of instruction.

According to García and Hesson (2015), in order to employ a translanguaging framework, schools must have translanguaging practices both at the macro- and micro-levels: in the school organizational and management level, as well as in teachers' discourse to teach multilingual learners meaningfully. The new Finnish core curriculum calls for what García and Hesson term a translanguaging space, by mandating that all students in basic and upper secondary education are able to use their whole linguistic repertoire for the purposes of learning (National Agency of Education, 2014; National Agency of Education 2015). In addition, as also reflected in the Finnish curriculum, a strong emphasis is placed on Finns learning additional languages. Our experience in schools, however, is that this positive orientation to multilingualism does not necessarily extend to the home languages of recent immigrants, particularly to languages like Arabic, Somali and Kurdish. Even in schools where there are home language teachers, support for home language instruction is not necessarily universal. In their study regarding home language teachers in Finland, Tarnanen, Kauppinen and Ylämäki (2017), found that there was no collaboration between the home language teachers and other teachers at the school. Moreover, home language support was not provided for learning other subjects. 


\section{RESEARCH CONTEXT}

Finland, the site of this study, is officially a bilingual country. Finnish and Swedish are the national languages, and in northern Finland, the Sami language has an official status. Further, Romani, Karelian, and Finnish and Finnish-Swedish sign languages are recognized as national minority languages. During the last decade, migration into Finland has increased considerably. At the moment, the growth in population is based completely on migration. (Statistics of Finland, 2016.) This demographic change has also brought change to many classrooms. In $2015,5.7 \%$ of students in basic education had a home language other than Finnish, Swedish or Sami, the three official languages of Finland. During the past 10 years, the number of multilingual learners has grown especially in the largest cities (National Agency of Education, 2017.)

Finland has always been a multilingual country, and all language groups have a constitutional right to maintain and develop their own languages. However, instruction in Finnish schools is mainly monolingual, though all Finnish students are expected to eventually learn at least two languages in addition to their mother tongue (typically Finnish or Swedish), and thus they could all be considered multilingual. However, in Finnish policy documents, linguistic diversity has mainly referred to migrant students (Zilliacus, Holm \& Sahlström, 2017).

The new core curriculum, established in 2016 for basic and upper secondary education, introduced new perspectives into the Finnish school context, such as linguistically responsive teaching. The guidelines require every teacher to take into account the challenges language poses for learners. It also states that all students should be able to use their whole linguistic repertoire as a resource for learning. (National Agency for Education, 2014; National Agency for Education 2015.) In order to assure that teachers in Finland are prepared to meet the demands of the new curriculum and address the increasing multilingualism among their students, it is important to understand the beliefs they have about multilingualism and about teaching multilingual learners. This study examines what kind of ideologies Finnish teachers have about multilingualism of Finnish language learners and teaching these multilingual learners. Further, it studies, whether these ideologies reflect the reality of the new curriculum, and what factors lay behind these ideologies.

\section{RESEARCH QUESTIONS}

In order to understand the aims mentioned above, this study was framed by the following questions:

RQ 1: What are Finnish teachers' ideologies about multilingualism and about teaching multilingual learners?

RQ 2: How do these Finnish teachers justify their beliefs that support either monolingual or multilingual ideologies? 
RQ 3: What factors are related to these teachers' ideologies?

\section{METHODS}

\subsection{Participants}

A total of 820 teachers participated in this study. Of the respondents, $78 \%$ were female, $21 \%$ male and $1 \%$ other. The mean age of the participants was 41 years. Table 1 presents the distribution of different teaching areas of the respondents. Only $13 \%$ of the respondents had had some training related to linguistically responsive teaching either as a part of their teacher studies or as in-service teacher training. Of the teachers, $87 \%$ reported not having any kind of training in linguistically responsive teaching.

TABLE 1. The distribution of the respondents to the different teaching areas

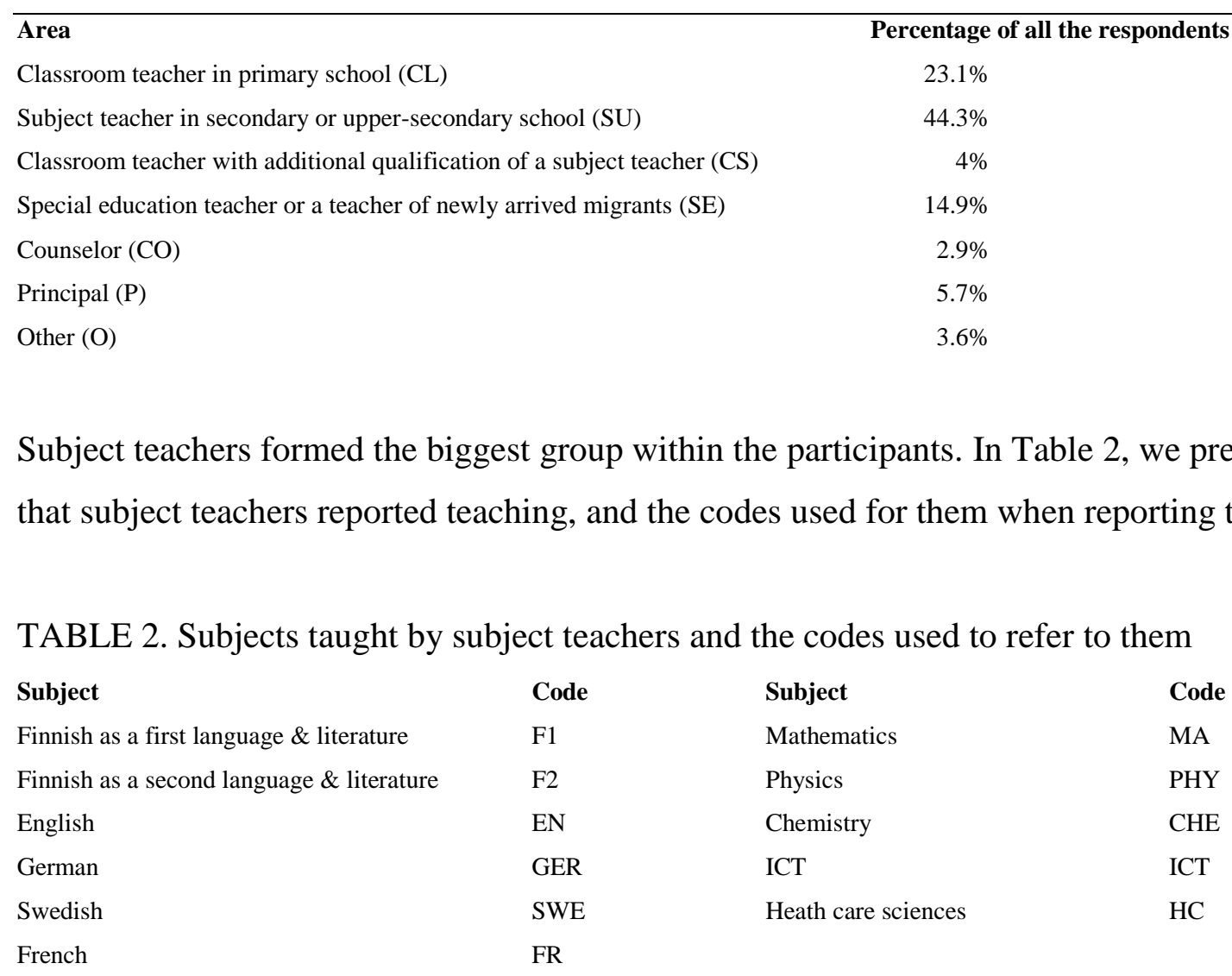

\subsection{Instrument and data analysis}

We collected the data for this study in an online survey during spring 2016. The survey was based on a preliminary version of a survey on linguistically and culturally responsive teaching by Milbourn, Viesca and Leech (2017), which builds on the framework of linguistically responsive teaching by Lucas \& Villegas (2013). Two of the authors translated and adapted the survey to fit the Finnish context. It was then reviewed by the National Agency of Education and by scholars 
working in The Finnish Network for Language Education Policies and in the Centre of Applied Linguistics. Based on the comments, we modified and finalized the survey in cooperation with a statistician, and transformed it into an online survey. We tested the reliability of the survey by looking at Cronbach alphas during analysis.

We advertised the survey on various email lists, on social media, on the websites of the journal of the Finnish teachers' trade union, Opettaja, and the Association of the Finnish as a second language teachers, as well as at the national educational fair, EDUCA, in January 2016. In addition, we sent a link to the survey and a cover letter to all the local education departments in Finland, either in Finnish or in Swedish (depending on the language of the department), and asked them to pass it on to all the teachers in the area. The cover letter and the first page of the online survey contained information about the study, including information about the purpose of the study and the protection of the data collected. It also included an explanation that the term multilingual learner used in the study referred to multilingual Finnish language learners from a migrant background. Participants were informed that by filling out the survey they gave a written consent to participate in the study. As the number of people who received or saw the link is not known, it was not possible to count the participation percentage. .

The survey included both Likert scale (1-5) statements and open-ended questions. This article reports on the analysis of a part of the survey. The Likert-scale statements analyzed in this study are presented in Table 3. One open-ended question "Should teachers have a "Finnish only"policy during their lessons? Why or why not?" was included to uncover the specific views held by teachers related to monolingual vs. multilingual ideologies.

TABLE 3. Statements included in the analysis.

Language, culture and identity are intertwined.

Language is a minor aspect of one's identity.

People can be discriminated because of their language

The social status of a language is related to the power the people who speak that language have in the society

I feel uncomfortable when I am in a group and others are speaking a language I do not know.

It is important for teachers to encourage multilingual learners' families to use Finnish as much as possible at home.

Multilingual learners who maintain their home language have difficulty learning Finnish.

A multilingual learner's home language development is a
It is unethical to prohibit the use of students' home language in the classroom.

It is important for teachers to ask multilingual learners questions about their home language.

Teachers should allow students to write in their home language. It is important for teachers to ask multilingual learners to teach others in the classroom words and/or phrases in their home language.

Teachers should use materials in class that reflect the cultural, racial/ethnic, and/or linguistic backgrounds of their multilingual learners.

It is important for teachers to draw on students' proficiency in their home language when teaching Finnish.

Teachers should advocate for Finnish language development support for their multilingual learners.

The responsibility to learn Finnish well rests primarily on the 
We analyzed the quantitative data with IBM SPSS version 23 by describing frequencies, and by using one-way ANOVAs, and t-tests in the following manner: We answered research question 1 by looking at the frequencies of all the Likert-scaled statements included in this study, and by content analyses of the answers to the open-ended question. Two of the authors did the content analyses independently (the inter-rater reliability was over 95\%). The analyses revealed three main content categories (advocacy, allowance and denial of multilingualism), which we describe and discuss more specifically in the results section.

To be able to answer research question 2 concerning teachers' justifications for either monolingual or multilingual ideologies, the same two authors analyzed the answers to the openended question using content analysis. First, we independently coded the data preliminarily to determine the themes emerging from the data. Second, we discussed the emerging themes together, and then we did a second analysis, again independently. The results of the separate analyses were compared with the inter-rater reliability found to be over $95 \%$. In reporting the responses to the open-ended question, we use codes to refer to the respondents' teaching area (see Table 1), to the subjects taught (Table 2) and the running numbers of the respondents.

We answered the research question 3 by using one-way ANOVAs and multiple comparisons to compare groups of teachers to each other according to different variables: work experience with students with migrant background (in years), work experience in total (in years), training in linguistically responsive teaching, and attitudes toward the use of students' home languages in instruction. The last variable was formed based on the analyses of the open-ended question for RQ1. The variable regarding awareness of linguistically responsive teaching was based on our previous work (Authors 1-3, in review).

\section{RESULTS}

The results in this section are organized according to the research questions presented above in the following order: 1) teachers' beliefs and ideologies related to multilingualism and teaching multilingual Finnish language learners; 2) teachers' arguments used to justify either monolingual or multilingual ideologies and 3) underlying factors found to be related to teachers' ideologies about migration related multilingualism and teaching multilingual Finnish language learners. 
5.1 Teachers' beliefs and ideologies related to multilingualism and teaching multilingual Finnish language learners

Our results indicate that teachers' beliefs related to multilingualism reflected an awareness of the current realities (see Table 4 for the frequency of the teachers' responses to the statements). For example, most of the teachers $(85 \%)$ believed that people can be discriminated against based on their language, and more than half of the teachers (59.5\%) agreed that the social status of a language is related to the power the people who speak that language have in society. Most of the teachers $(81.8 \%)$ considered language to be an important part of one's identity, and that language, culture and identity are intertwined $(82.6 \%)$.

The teachers' beliefs were also quite positive in the sense that the teachers believed that it is important to take the backgrounds of the students into account: Over half of the teachers $(60 \%)$ considered that using materials that reflect the cultural, racial/ethnic, and/or linguistic backgrounds of their multilingual learners as beneficial. However, $16.7 \%$ of the teachers did not promote the use of these kinds of materials.

Most of the teachers $(81.7 \%)$ thought it was beneficial to carefully examine school policies with regard to the potential impacts on multilingual learners. Moreover, more than half of the teachers $(54.9 \%)$ did not think that the primary responsibility to learn Finnish rested on the multilingual learners. However, almost a third (29.1\%) of the teachers did. 
Table 4. The frequency of the teachers' responses to the statements regarding multilingualism and teaching multilingual learners.

\begin{tabular}{|c|c|c|c|c|c|}
\hline Statement & $\begin{array}{c}\text { Strongly } \\
\text { agree } \\
(\%)\end{array}$ & $\begin{array}{l}\text { Agree } \\
(\%)\end{array}$ & $(\%)$ & $\begin{array}{c}\text { Disagree } \\
\text { (\%) }\end{array}$ & $\begin{array}{r}\text { Strongly } \\
\text { disagree } \\
(\%)\end{array}$ \\
\hline Language, culture and identity are intertwined. & 57.7 & 24.9 & 1.8 & 6 & 8.5 \\
\hline Language is a minor aspect of one's identity. & 2.7 & 8.3 & 5.9 & 38.8 & 43 \\
\hline $\begin{array}{l}\text { People can be discriminated because of their } \\
\text { language. }\end{array}$ & 46.1 & 38.9 & 6.7 & 4.8 & 3 \\
\hline $\begin{array}{l}\text { The social status of a language is related to the } \\
\text { power the people who speak that language have } \\
\text { in the society. }\end{array}$ & 18.4 & 41.1 & 26.3 & 9.5 & 3 \\
\hline $\begin{array}{l}\text { It is unethical to prohibit the use of students' } \\
\text { home language in the classroom. }\end{array}$ & 22.9 & 30.4 & 20.2 & 19.4 & 5.5 \\
\hline $\begin{array}{l}\text { It is important for teachers to ask multilingual } \\
\text { students questions about their home language. }\end{array}$ & 32.3 & 40.5 & 15.7 & 7.9 & 2.4 \\
\hline $\begin{array}{l}\text { Teachers should allow students to write in their } \\
\text { home language. }\end{array}$ & 6.3 & 20.2 & 30.5 & 31.6 & 10.1 \\
\hline $\begin{array}{l}\text { It is important for teachers to ask multilingual } \\
\text { students to teach others in the classroom words } \\
\text { and/or phrases in their home language. }\end{array}$ & 24.3 & 42.6 & 20 & 8.5 & 3.7 \\
\hline $\begin{array}{l}\text { Teachers should use materials in class that } \\
\text { reflect the cultural, racial/ethnic, and/or } \\
\text { linguistic backgrounds of their linguistically and } \\
\text { culturally diverse students. }\end{array}$ & 15.9 & 44.1 & 22.3 & 12.8 & 3.9 \\
\hline $\begin{array}{l}\text { It is important for teachers to draw on students' } \\
\text { proficiency in their home language when } \\
\text { teaching Finnish. }\end{array}$ & 19.4 & 43.4 & 27.1 & 6.8 & 2.2 \\
\hline $\begin{array}{l}\text { Teachers should advocate for Finnish language } \\
\text { development support for their multilingual } \\
\text { students. }\end{array}$ & 59.8 & 33.5 & 2.9 & 1.3 & 1.8 \\
\hline $\begin{array}{l}\text { The responsibility to learn Finnish well rests } \\
\text { primarily on the multilingual students. }\end{array}$ & 6.5 & 22.6 & 14.8 & 41.7 & 13.2 \\
\hline $\begin{array}{l}\text { I feel uncomfortable when I am in a group and } \\
\text { others are speaking a language I do not know. }\end{array}$ & 16.2 & 37.4 & 15.1 & 19.8 & 10.7 \\
\hline $\begin{array}{l}\text { It is important for teachers to encourage } \\
\text { multilingual students' families to use Finnish as }\end{array}$ & 32.6 & 25.1 & 15.9 & 16.2 & 9.9 \\
\hline
\end{tabular}




\begin{tabular}{|c|c|c|c|c|c|}
\hline Multilingual students who maintain their home & 3.7 & 3.2 & 7 & 29.3 & 56.1 \\
\hline \multicolumn{6}{|l|}{ language have difficulty in learning Finnish. } \\
\hline A multilingual students' home language & 45.1 & 37.4 & 11.1 & 3.2 & 1.8 \\
\hline \multicolumn{6}{|l|}{ development is a valuable asset to his or her } \\
\hline \multicolumn{6}{|l|}{ Finnish language development. } \\
\hline It is beneficial for teachers to carefully examine & 31.1 & 50.6 & 10.9 & 4.8 & 1.5 \\
\hline \multicolumn{6}{|l|}{ school policies for their potential impacts on } \\
\hline linguistically and culturally diverse students. & & & & & \\
\hline
\end{tabular}

Teachers' beliefs about implementing multilingual practices in the classroom were somewhat contradictory. The teachers considered it important to ask questions about students' home languages and to ask them to teach phrases in their languages to other students (see Table 4). However, when it came to the actual use of different languages for learning, the teachers' beliefs were more negative, and did not appear to support multilingualism in the classroom. A quarter of the respondents felt that it was ethical to prohibit the use of home languages in multilingual classrooms, while $53.3 \%$ considered it unethical. Moreover, $41.7 \%$ of the teachers reported that in the school context, multilingual Finnish language learners should not be allowed to write in their home languages. However, 26.5\% did approve of allowing writing in the multilingual learners' home language. Additionally, when teachers were asked whether they translate or ask someone else to translate key concepts into the multilingual learners' home languages in a typical teaching week, $58.9 \%$ of the teachers reported never doing this. One fifth of the teachers $(22.1 \%)$ reported doing this once a week, $9.7 \%$ two or three times a week, and only $9.3 \%$ four or more times a week.

Nearly two thirds of the teachers $(62.8 \%)$ reported that it was important for teachers to draw on the students' proficiency in their home language when teaching Finnish. Similarly, most of the teachers (82.5\%) agreed that multilingual Finnish language learners' home language development is a valuable asset to their Finnish language development. When teachers were asked in the openended question whether they should have a "Finnish only" policy during their lessons, only 25.1\% of the teachers disagreed, and in their answers, they reported ideologies advocating the use of multiple languages. Thus, they were categorized as having an advocacy approach in their multilingual ideologies. More than a third (35.6\%) felt that depending on the situation, multilingual learners could sometimes use their home languages in the classroom. These teachers were categorized as having an allowance approach since they did not actively promote the use of minority languages in the classroom. However, over a third (39.2\%) of the teachers reported that the home languages should be always denied during lessons. Thus, they were categorized as having a denial approach regarding the use of multiple languages in the classroom. 
Teachers considered Finnish language development to be important, and almost all of the teachers $(93.3 \%)$ considered it to be the teachers' responsibility to advocate for Finnish language development support for their multilingual learners. More than half of the teachers $(54.9 \%)$ also believed that the responsibility to learn Finnish well did not rest primarily on the students. However, $29.1 \%$ of the teachers considered it to be primarily the students' responsibility. The importance of Finnish language development was also reflected in the responses to the statement arguing that it is important for teachers to encourage multilingual families to use Finnish at home as much as possible: more than half of the teachers (57.7\%) agreed with the statement and only $26.1 \%$ of the teachers disagreed. However, most of the teachers $(85.4 \%)$ disagreed when asked whether maintaining home language creates difficulty in learning Finnish. Tolerance for being surrounded by different languages was not very high: in response to the statement asking about feeling discomfort when in a group of people speaking a language one does not understand, over half of the teachers $(53.6 \%)$ reported that they would feel uncomfortable, while $30.5 \%$ reported the opposite.

\subsection{Teachers' arguments to justify either monolingual or multilingual ideologies}

We also investigated how teachers justified their arguments related to monolingual or multilingual ideologies in the classroom. This was done by content analysis of the teachers' answers to the openended question "Should teachers have a "Finnish only" policy during their lessons? Why or why not?" There were two main themes that emerged from the arguments the teachers used to justify their monolingual or multilingual ideologies. The first one was "allowing the use of home languages in the classroom "with 6 sub-themes, and the second one was "not allowing the use of home languages in the classrooms" with 4 sub-themes. These are all presented in Table 5.

TABLE 5. Arguments to justify the monolingual or multilingual ideologies

\begin{tabular}{|c|c|c|c|c|}
\hline MAIN & Allowing the students to use their & $\mathrm{N}=480$ & Not allowing the students to use their & $\mathrm{N}=204$ \\
\hline THEME & home languages in the classrooms & $\%$ & home languages in the classrooms & $\%$ \\
\hline \multicolumn{5}{|l|}{$\mathbf{S}$} \\
\hline SUB & Curriculum requires it & 1.5 & Main aim is to learn Finnish language & 52.9 \\
\hline THEME & It supports learning & 73.8 & Home languages are used for bullying & 39.2 \\
\hline \multirow[t]{4}{*}{$\mathbf{S}$} & Human rights require it & 6.2 & Learning occurs only in Finnish & 2.5 \\
\hline & Usefulness of multilingualism & 6.8 & Teacher has to understand the language & 5.4 \\
\hline & Valuing home languages & 3.2 & & \\
\hline & Everyone's freedom to expression & 8.5 & & \\
\hline
\end{tabular}

Most of the teachers allowed the use of home languages in the classroom. Further, most of these teachers (73.8\%) justified the use of home languages with the argument that it supports learning. The rest of the justifications in this group were linked to the ideology that home languages are 
valuable per se, or that home language use is a human right. Of the teachers who did not allow the use of home languages, $52.9 \%$ argued that the main aim at school is to learn the Finnish language, and $39.2 \%$ reported home languages being mainly used for bullying.

Looking more precisely at the language ideologies that the teachers' answers reflected, there were three other categories of language policies that emerged: within the first main theme "allowing the use of home languages in the classroom" the teachers' multilingual ideologies reflected two categories: advocacy (25.1\%) and allowance (35.6\%). Within the second main theme "not allowing the use of home languages in the classrooms", the teachers were categorized as having a denial ideology (39.2\%). Next, we will present examples of teachers' responses regarding their views of multilingualism in the classroom.

The teachers who reported encouraging their students to use their home languages during the lessons were categorized as advocating for multilingualism and multilingual policies. Teachers in this category advocated the use of home languages for the following reasons: learning is improved when all linguistic resources are used, multilingualism is beneficial for the individual and the society, and the home language is an important part of identity and everyone's right. The following excerpts illuminate teachers' advocacy ideology:

It may be beneficial to use the home languages for learning difficult topics, for example in pairs. You have to trust the learners, even though you do not understand the language. 35EN/FR

Diversity is richness. The right for your own language is extremely important. 41EN/SWE Multilingualism is beneficial now and in the future, as long as the students are able to separate the structures of different languages. $45 \mathrm{~F} 2$

That was already experienced by Sami people and those who experienced that have lots of traumas related to inequity, feeling guilty and unfairness. 160MA/PHY/CHE

The teachers who did not actively promote the use of home languages, but allowed their use in the classrooms occasionally, were categorized as having an "allowance" ideology related to multilingualism. These teachers understood that it is sometimes important for the students to be able to use their home languages, for example to clarify the content of the lesson. However, Finnish language learning was considered as the primary goal, whereas the use of home languages was an exception. The following excerpts reflect the teachers' ideology in this category:

Speaking Finnish is essential for learning Finnish. There might be some occasions, when it is better to use some other languages, for example for understanding some content related issues. $42 \mathrm{HC}$

The language of teaching has to be Finnish, always. Sometimes, in my opinion, learners could be allowed to express aloud a task in their home language. $48 \mathrm{~F} 1$ 
Among the teachers surveyed, 39.2\% did not allow their students to use their home languages during the lessons, and thus, their multilingual ideology was categorized as denial. Mainly, the teachers denied the use of home languages because they thought it would hinder the learning of both content and the Finnish language. Further, they reported that teachers have to be in control and be able to understand their students at all times:

Science is full of concepts, and exact vocabulary is the basis for learning the topics. If there are no words, there can't be learning science either. In these classes, only Finnish has to be spoken and you have to be extremely careful with the concepts and terminology you use. 44MA/PHY/CHE

The teacher has to know what is going on during the lessons and what the students are talking about. Moreover, speaking Finnish benefits learning Finnish. 97MA/PHY/CHE/ICT

\subsection{Underlying factors related to teachers' beliefs about teaching multilingual learners}

The differentiating factors related to teachers' beliefs, (teachers' experience in teaching migrant background students, their overall teaching experience, their teaching area, and their awareness and training related to linguistically responsive teaching, as well as their multilingual ideologies) were investigated with one-way ANOVAs and independent samples t-tests. The results of the analysis are presented in Table 6. 
Table 6. Factors related to teachers' beliefs about multilingualism and teaching multilingual learners.

\begin{tabular}{|c|c|c|c|c|}
\hline \multirow[b]{2}{*}{ Experience in teaching migrant students } & $\mathbf{F}$ & df & $\mathbf{p}$ & Multiple comparisons \\
\hline & & & \multicolumn{2}{|r|}{ Work experience in years } \\
\hline $\begin{array}{l}\text { I feel uncomfortable when I am in a group and others are } \\
\text { speaking a language I do not know. }\end{array}$ & 4.180 & 2,758 & .016 & $1-5$ vs. $>5 \mathrm{p}=.015$ \\
\hline $\begin{array}{l}\text { It is important for teachers to encourage multilingual } \\
\text { students' families to use Finnish as much as possible at } \\
\text { home. }\end{array}$ & 10.815 & 2,761 & $<.001$ & $\begin{array}{l}<5 \text { vs. }>5 \mathrm{p}<.001 \\
1-5 \text { vs. }>5 \mathrm{p}=.005\end{array}$ \\
\hline $\begin{array}{l}\text { Multilingual students who maintain their home language } \\
\text { have difficulty in learning Finnish. }\end{array}$ & 4.332 & 2,757 & .013 & $<1$ vs. $>5 \mathrm{p}=.037$ \\
\hline $\begin{array}{l}\text { A multilingual students' home language development is a } \\
\text { valuable asset to his or her Finnish language development. }\end{array}$ & 11.365 & 2,753 & $<.001$ & $\begin{array}{l}<1 \text { vs. }>5 \mathrm{p}<.001 \\
1-5 \text { vs. }>5 \mathrm{p}=.002\end{array}$ \\
\hline $\begin{array}{l}\text { It is beneficial for teachers to carefully examine school } \\
\text { policies for their potential impacts on linguistically and } \\
\text { culturally diverse students. }\end{array}$ & 4.616 & 2,754 & .010 & $<1$ vs. $>5 \mathrm{p}=.009$ \\
\hline $\begin{array}{l}\text { Teachers should advocate for Finnish language } \\
\text { development support for their multilingual students. }\end{array}$ & 8.034 & 2,759 & $<.001$ & $<1$ vs. $>5 \mathrm{p}<.001$ \\
\hline
\end{tabular}

Teaching area

(see Table 1 for the codes)

It is important for teachers to ask multilingual students questions about their home language.

Teachers should allow students to write in their home language.

It is important for teachers to ask multilingual students to teach others in the classroom words and/or phrases in their home language.

Multilingual students who maintain their home language have difficulty in learning Finnish.

A multilingual students' home language development is a valuable asset to his or her Finnish language development.

$\begin{array}{lllll}4.490 & 3,803 & .004 & \text { SU vs. SE } \mathrm{p}=.002 \\ 2.932 & 3,802 & .033 & \text { CL vs. SE } \mathrm{p}=.041 \\ 7.700 & 3,805 & <.001 & \text { CL vs. SU } \mathrm{p}=.001 \\ 4.417 & 3,805 & .004 & \text { CL vs. SE } \mathrm{p}=.014 \\ & & & \text { C/P vs. SE } \mathrm{p}=.023 \\ 3.015 & 3,803 & .029 & \text { CL vs. SE } \mathrm{p}=.024 \\ & & & \\ 2.772 & 3,805 & .041 & \\ & & & & \\ & & & & \end{array}$

Teachers should use materials in class that reflect the cultural, racial/ethnic, and/or linguistic backgrounds of their linguistically and culturally diverse learners.

Teachers should advocate for Finnish language development support for their multilingual students.

The responsibility to learn Finnish well rests primarily on multilingual learners.

\section{Linguistically responsive training}

Language, culture and identity are intertwined.

$4.588 \quad 1,810 \quad .032$

Language is a minor aspect of one's identity.

$12.324 \quad 1,808<.001$

People can be discriminated because of their language.

$6.333 \quad 1,815 \quad .012$

Teachers should advocate for Finnish language

$8.746 \quad 1,814 \quad .003$

development support for their multilingual students.

\section{Allowing the use of the home languages}

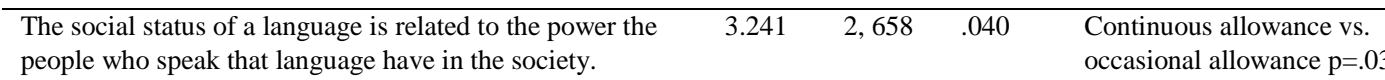




\begin{tabular}{|c|c|c|c|c|}
\hline $\begin{array}{l}\text { It is important for teachers to encourage multilingual } \\
\text { students' families to use Finnish as much as possible at } \\
\text { home. }\end{array}$ & 5.369 & 2,809 & .005 & $\begin{array}{l}\text { Scarce awareness vs. adequate } \\
\text { awareness } p=.004\end{array}$ \\
\hline $\begin{array}{l}\text { Multilingual students who maintain their home language } \\
\text { have difficulty in learning Finnish. }\end{array}$ & 7.958 & 2,807 & $<.001$ & $\begin{array}{l}\text { No awareness vs. adequate } \\
\text { awareness } p=.025 \\
\text { Scarce awareness vs. adequate } \\
\text { awareness } p=.001\end{array}$ \\
\hline $\begin{array}{l}\text { A multilingual students' home language development is a } \\
\text { valuable asset to his or her Finnish language development. }\end{array}$ & 10.290 & 2,804 & $<.001$ & $\begin{array}{l}\text { No awareness vs. adequate } \\
\text { awareness } p=.002 \\
\text { Scarce awareness vs. adequate } \\
\text { awareness } p=.001\end{array}$ \\
\hline $\begin{array}{l}\text { It is beneficial for teachers to carefully examine school } \\
\text { policies for their potential impacts on linguistically and } \\
\text { culturally diverse students. }\end{array}$ & 10.725 & 2,805 & $<.001$ & $\begin{array}{l}\text { No awareness vs. adequate } \\
\text { awareness } p=.006 \\
\text { Scarce awareness vs. adequate } \\
\text { awareness } p<.001\end{array}$ \\
\hline $\begin{array}{l}\text { It is important for teachers to ask multilingual students } \\
\text { questions about their home language. }\end{array}$ & 3.639 & 2,806 & .027 & $\begin{array}{l}\text { No awareness vs. adequate } \\
\text { awareness } \mathrm{p}=.044\end{array}$ \\
\hline $\begin{array}{l}\text { It is important for teachers to draw on students' proficiency } \\
\text { in their home language when teaching Finnish. }\end{array}$ & 4.968 & 2,807 & .007 & $\begin{array}{l}\text { No awareness vs. adequate } \\
\text { awareness } \mathrm{p}=.017\end{array}$ \\
\hline $\begin{array}{l}\text { Teachers should advocate for Finnish language } \\
\text { development support for their multilingual students. }\end{array}$ & 8.617 & 2,804 & $<.001$ & $\begin{array}{l}\text { No awareness vs. adequate } \\
\text { awareness } p=.005 \\
\text { Scarce awareness vs. adequate } \\
\text { awareness } p=.002\end{array}$ \\
\hline
\end{tabular}

The general teaching experience in number of years was not a distinguishing factor, but teachers' experience in teaching migrant students had a significant influence on some of their beliefs related to multilingualism (see Table 6). Those who had been teaching students with migrant background for more than 5 years (39.6\% of the teachers) had the most supportive beliefs about multilingualism as reflected in how they would advise families in using their home languages. Moreover, these teachers were also more aware that maintaining the home language does not cause difficulties in learning the Finnish language. They also reported feeling less uncomfortable when being in a group where others speak a language that they do not understand. In addition, the more experienced teachers with migrant students considered it more beneficial to carefully examine school policies and to advocate for Finnish language development for their multilingual learners. Finally, the more experienced teachers agreed more strongly than the less experienced teachers that the home language is a valuable asset for the development of the Finnish language.

The respondents' teaching area influenced their beliefs as well. Special education teachers and teachers of newly arrived migrants differed significantly from class (1-6) teachers, subject teachers, principals and counselors, for example, in their responses related to the use of home languages in learning. These teachers agreed more than other respondents that teachers should ask questions about students' languages, let them teach phrases in their languages to other students, and 
that they should be allowed to write in their languages. Moreover, these teachers considered students' home languages as valuable assets for the students' Finnish language development more than the other teachers. Of these teachers, $14.8 \%$ reported that they had had some training about linguistically responsive teaching which is in line with the $13 \%$ of participants overall who had received training in linguistically responsive teaching. Thus, having training in linguistically responsive teaching alone does not explain the more positive beliefs of this group compared to the other teachers.

Teachers' training related to linguistically responsive teaching was related to three areas: teachers' perceptions of language as a part of identity; language being a possible reason for discrimination; and teachers' role as advocates for students' Finnish language development. Teachers' awareness of linguistically responsive teaching influenced their beliefs significantly. The more aware the teachers were about the challenges that developing language skills pose, the more supportive beliefs they reported having in relation to multilingualism. For example, they had stronger opinions about home languages being valuable assets for Finnish language development than teachers with less awareness.

Teachers' attitudes toward allowing students use of their home language in content instruction was only related to their beliefs on the possibility of language being a reason for discrimination. There was a significant difference between teachers who advocated for the use of home languages continuously during the lessons ( $25.1 \%$ of the teachers), and those who only allowed it occasionally (35.6\% of the teachers); interestingly, however, the latter ones were more aware of the possible discriminative aspect of language.

\section{DISCUSSION}

The results of this study indicate that Finnish teachers' attitudes towards multilingualism and teaching multilingual Finnish language learners are generally positive. However, the teachers surveyed in this study had varying beliefs regarding multilingualism and multilingual ideologies and mixed views regarding the use of home languages as a learning resource. A majority of the teachers surveyed believed it to be beneficial to examine school policies, and they emphasized the teachers' role in supporting multilingual learners. However, even though home languages were, for the most part, considered as valuable assets for Finnish language development and as basic linguistic human rights (see Skutnabb-Kangas, 2008), and even though many teachers reported allowing their use in their classrooms, students' home languages were not always considered as resources for learning, particularly in subject area instruction. This is in line with previous findings from both international and Finnish national research (see Tarnanen et al., 2017; Taylor et al., 2008). Many teachers also promoted the use of Finnish instead of home languages in students' 
homes. These kinds of beliefs support monolingual ideologies (see Blommaert et al., 2006), and may contribute to the academic failure of language-minoritized learners (see García \& Hesson, 2015; Thomas \& Collier, 2002). Moreover, they are contrary to the recommendations the European Commission (2018) has given to their member states. Thus, even though the Finnish core curriculum (National Agency of Education, 2014; National Agency of Education 2015) creates the macro-level context for multilingual practices in school, what García \& Hesson, (2015) would label translanguaging spaces, if the teachers' ideologies do not support this view, the micro-level context might not be offered to students.

In previous research, it has been shown that there are benefits in using home languages for operating on higher cognitive level (e.g. Cummins, 1979, 2007). In this study, more than half of the teachers encouraged or at least allowed the use of home languages in the classroom. However, in their responses to questions about their beliefs about implementing multilingual practices, many of the teachers selected the option "I don't know" for statements related to the use of home languages in classrooms. This may indicate that many teachers lack sufficient knowledge about the importance of home languages in learning or that they do not know how to encourage students to draw on all of their linguistic resources. This suggests that teachers need more training targeted at promoting the use of students' home languages as an asset for learning in all subjects at school (see e.g. Cummins, 1979, 2007; García, 1991; Goldenberg 2008; Miramontes et al., 2011; Ovando et al., 2006; Slavin \& Cheung, 2005), and in how to enable students to gain their full potential in their languages other than the language of instruction (see Blommaert et al., 2006; Miramontes et al., 2011).

Most of the teachers in this study viewed it as highly important to advocate for Finnish language support for their multilingual Finnish language learners. However, more than half of the teachers also believed that multilingual families should use the Finnish language at home as much as possible. While this might be construed as promoting the students' multilingualism by gaining Finnish, these attitudes may overlook the benefits of the home language to further cognitive and conceptual development. In addition, this view fails to take into account its importance in affirming identity, creating family bonding, nurturing relationships and maintaining relations with relatives in the countries of origin (see also Delavan et al., 2017). Even though most teachers reported sometimes allowing the use of their students' home languages in their lessons, one fourth of the teachers reported having a "Finnish only" policy, arguing that the use of other languages would be a tool to bully others and exclude other students (and the teacher) from discussions. Moreover, they believed that the use of home languages would hinder learning Finnish. This confirms the perceptions reported by Tarnanen et. al. (2017), and indicates that not all Finnish teachers have sufficient knowledge about multilingual learners' language development and how to teach multilingual learners. Some of the justifications for the "Finnish only" policy reveal that when 
teachers were not able to understand the language used in their classroom, they felt that they did not have enough control over the situation. Similarly, more than half of the teachers reported that they would feel uncomfortable being in a group of people where a language they did not understand was being spoken.

Results of this study indicate that Finnish teachers' beliefs and ideologies are influenced by having participated in training related to linguistic responsiveness, as well as their working context, which is in line with previous studies (Borg, 2006; Richards, Tung \& Ng, 1992; Voet \& DeWever, 2016). The most significant factor related to beliefs supporting multilingual ideologies was experience in teaching migrants, while overall experience in teaching was not. This finding indicates that especially pre-service teachers need opportunities to practice teaching in linguistically diverse contexts. Another significant factor was teachers' awareness of linguistically responsive teaching (see also Author 1 et al., in review). These findings suggest that both pre- and in-service teachers would benefit from professional development.

The findings from this study of Finnish teachers' beliefs and ideologies are especially timely given the Finnish National Curriculum's requirement that all teachers build on every student's entire linguistic repertoire. The curriculum recognizes that all students, not only multilingual Finnish language learners, benefit from an environment and classroom culture that values languages. This is in line with Skutnabb-Kangas' $(2008 ; 2017)$ idea of linguistic human rights. Under the mandate of the national curriculum, every teacher can decide to use multilingual practices instead of monolingual ones as often as it is meaningful. The question is how to best implement these practices at the micro-level in each classroom as an integral part of teachers' pedagogical strategies. Because teacher training has a significant influence on teachers' beliefs, it is crucial to provide more training about linguistically responsive teaching to all pre-service and practicing teachers.

The findings of this study also coincide with the recommendations from a recent report about language resources in Finland (Pyykkö, 2017). The report points to the need for targeted professional development so that every teacher can become more linguistically aware and responsive in their work. Positively, in Finland, the Finnish Ministry of Education and Culture has begun to provide substantial funding to a number of projects to reform teacher education for example to align with the new curriculum. One of these, DivEd (www.dived.fi), is focused on integrating linguistically responsive and culturally sustaining practices into pre- and in-service training at seven institutions of higher education. The findings from this study point to specific areas that can be targeted for this professional development. 
It is suggested above (see also Pyykkö, 2017) that the National Agency of Education, should work together with schools and teacher training departments to develop ways to recognize, support and utilize multilingualism as a resource much more than is currently evident. The findings of this study can provide directions for such collaboration. This professional development can draw on research that supports the benefits of multilingualism (see e.g. Mehmedbegovič \& Bak, 2017), and the use of multilingual practices in classrooms (see Beeman \& Urow, 2012; Escamilla et al. 2013; García \& Wei, 2014). Our findings suggest that one specific area to target is the promotion of positive multilingual consciousness. This means making students' languages more visible and encouraging teachers to value all languages, in other words, to take on an advocacy ideology for multilingualism in the classroom.

\section{CONCLUSIONS}

The results of this study confirm our own experiences that, too often, children are not allowed to speak their own languages at school. One consequence of this is that they are unable to connect their home language to the school context. However, the recommendation of the Council of Europe $(1740,2006)$ encourages migrant adolescents to study both their own languages as well as the language of their new country. This could be done by highlighting the practice of translanguaging and encouraging students to make use of all their languages simultaneously. Likewise, the report of the Finnish Ministry of Culture and Education (Pyykkö, 2017) emphasizes the importance of languages in information-seeking and that teaching delivered in home language improves learning outcomes.

García and Hesson (2015) suggest that operating in and across many languages, i.e. translanguaging, is a critical $21^{\text {st }}$ century skill and an "important communicative resource" (p. 230). Thus, it is important that every student has the possibility to study in a context where all their languages are seen as a potential for learning. Instruction should be organized to maximize students' ability to take what they know in one language and express it through another. This requires creating a variety of distinct and meaning-enriched opportunities to use language and learn concepts that are intentionally linked (X et al., 2011). Teachers need to understand that if students are allowed to use their whole linguistic repertoire, they are more likely to develop their cognitive skills more holistically. At the same time, promoting multilingualism indicates to students that they are valuable as they are, encouraging students to reach their full potential. Every language is valuable in its own right even if it does not bring an external economic benefit with it, as studying home languages increases self-confidence and builds positive identity (Pyykkö, 2017). However, 
our findings suggest that teachers need to develop a willingness to ease their control in the classroom and to be comfortable with their own lack of knowledge of students' languages.

As the present study demonstrates, language awareness significantly influences teachers' beliefs related to multilingualism and teaching multilingual learners. Thus, professional development is needed to strengthen both attitudes and practices that value linguistic diversity. We recommend that teacher training should explicitly advocate for valuing multilingualism. It should reflect the view that the multilingual nature of schools all over the world requires "teacher educators to put language difference at the center of the educational enterprise" (García, 2008, p. 393). This is especially important for multilingual learners from migrant backgrounds that are in the process of learning Finnish.

In conclusion, many Finnish teachers have positive ideologies related to multilingualism and teaching multilingual Finnish language learners. Yet, work remains to ensure that all teachers have knowledge about and specific strategies for using all the languages of their learners as resources for learning, in order to ensure successful academic outcomes for multilingual students. It is a challenge for future teacher development to strengthen ideologies that value and utilize linguistic diversity at schools to make sure that all students, both monolingual and multilingual, benefit from an atmosphere that values languages. Lastly, it is important that all teachers see how providing students with a voice will promote success for all students. Finnish teachers have a unique opportunity to do so given the macro level support in the National Curriculum. Teachers around the globe can benefit from understanding how to take the advocacy for multilingualism ideology to the classroom itself. 


\section{REFERENCES}

Althusser, L. (1976). Ideology and Ideological State Apparatuses. In A. Sharma \& A. Gupta (Eds.). Essays on Ideology (pp. 1-60). Oxford: Blackwell.

Antón, E., Thierry, G., Goborov, A., Anassagasti, J. \& Duñabeitia J. A. (2016). Testing bilingual educational methods: A plea to end the language-mixing taboo. Language Learning, 66(52), 29-50. doi.org/10.1111/lang.12173

Author 1, Author $2 \&$ Author, 4 (in review).

Author 4 (2011).

Barcelos, A. M. F. (2003). Teachers' and students' beliefs within a Deweyan framework: conflict and influence. In Kalaja, P. \& Barcelos, A. M. F. (Eds.). Beliefs about SLA: New research approaches (pp. 171-199). Dordrecht: Kluwer Academic Publishers.

Beeman, K. \& Urow, C. (2012). Teaching for Biliteracy. Philadelphia: Caslon.

Blommaert, J., Creve, \& Villaert (2006). On being declared illiterate: Language-ideological disqualification in Dutch classes for immigrants in Belgium. Language \& Communication, 26(1) 34-54. https://doi.org/10.1016/j.langcom.2005.03.004

Borg, S. (2006). Teacher cognition and language education: Research and practice. London: Continuum.

Canagarajah, S. (2011). Translanguaging in the classroom: Emerging issues for research and pedagogy. Applied linguistics review, 2, 1-28.

Chan, K. (2016). These are the most powerful languages in the world. World Economic Forum. https://www.weforum.org/agenda/2016/12/these-are-the-most-powerful-languages-in-theworld/

Collier, V. P., \& Thomas, W. P. (2007). Predicting second language academic success in English using the Prism Model. In J. Cummins \& C. Davison (Eds.), International handbook of English language teaching, Part 1 (pp. 333-348). New York: Springer.

Cummins, J. (1979). Linguistic interdependence and the educational development of bilingual children. Review of Educational Research, 49, 222-25. DOI: 10.2307/1169960

Cummins, J. (2000). Language, Power and Pedagogy: Bilingual Children in the Crossfire. Clevedon: Multilingual Matters

Cummins, J. (2007). Rethinking monolingual instructional strategies in multilingual classrooms. Canadian Journal of Applied Linguistics, 10, 221-240.

Cummins, J., Bismila, V., Chow, P., Cohen, P., Giampapa, F., Leoni, L., Sandhu, P. \& Sastri, P. (2005). Affirming Identity in Multilingual Classrooms. Educational Leadership 63(1), 3843. 
Cummins, J., Cohen, S. L. \& Giampapa, F. (2006). ELL Students speak for themselves: Identity Texts and Literacy Engagement in Multilingual Classrooms. http://www.curriculum.org/secretariat/files/ELLidentityTexts.pdf

Delavan, M. G., Valdez, V. E. \& Freire, J. A. (2017). Language as Whose Resource? When Global Economics Usurp the Local Equity Potentials of Dual Language Education, International Multilingual Research Journal, 11:2, 86-100, DOI: 10.1080/19313152.2016.1204890

DivEd. Developing linguistically responsive and culturally sustained teaching and teacher education. Retrieved on $18^{\text {th }}$ September 2017 from: www.dived.fi

Edwards, V. (2017). Literacy in Bilingual and Multilingual Education. In W. E. Wright, S. Boun \& O. García (Eds.), The Handbook of Bilingual and Multilingual Education (pp. 75-91). Oxford: Wiley.

Escamilla, K., Hopewell, S., Butvilofsky, S., Sparrow, W., Soltero-González, L., Ruiz-Figueroa, O. \& Escamilla, M. (2013). Biliteracy from the Start. Philadelphia: Caslon.

European Commission (2018). Council recommendation on improving the teaching and learning of languages. Retrieved on $15^{\text {th }}$ August 2018 from: https://ec.europa.eu/education/initiatives/european-education-area/improving-the-teachingand-learning-of-languages_en

Fitch, F. (2003). Inclusion, Exclusion, and Ideology: Special Education Students' Changing Sense of Self. The Urban Review 35(3), 233-252.

García, O. \& Hesson, S. (2015). Translanguaging frameworks for teachers: Macro and micro perspectives. In A. Yiacoumetti (Ed.), Multilingualism and Language in Education: Current Sociolinguistic and Pedagogical Perspectives from Commonwealth Countries (pp. 221242). Cambridge: Cambridge University Press.

García, O. Ibarra-Johnson, S. \& Seltzer, K (2016). The Translanguaging classroom: Leveraging student bilingualism for learning. Philadelphia: Caslon.

García, O. \& Otheguy, R. (2014). Spanish and Hispanic bilingualism. In M. Lacorte (Ed.), The Routledge handbook of Hispanic applied linguistics (pp. 639-658). New York: Routledge. García, O. \& Wei, (2014). Translanguaging: Language, Bilingualism and Education. New York: Palgrave MacMillan.

Gay, G. (2000). Culturally responsive teaching: Theory, research, and practice. New York: Teachers College Press.

Ladson-Billings, G. (1994). The dreamkeepers: Successful teachers of African American children. San Francisco, CA: Jossey-Bass.

Genesee, F. (1994). Educating second language children: The whole child, the whole curriculum, the whole community. Cambridge: Cambridge University Press. 
Goldenberg, C. (2008). Teaching English Language Learners: What the research does and does not say. American Educator, 8(23), 41-44. https://www.edweek.org/media/ell_final.pdf Hämäläinen, V. (2018). Vieraskieliset_kunnittain_2013_2017. [Foreign language speakers in different municipalities_2013_2017.] Personal information from Statistics of Finland, January 12.

James, W. (1913). Pragmatismi [Pragmatism]. Translated by K. W. Silfverberg. Helsinki: Otava. Ladson-Billings, G. (1995). Toward a theory of culturally relevant pedagogy. American Educational Research Journal, 32(3), 465-491.

Lilja, N., Luukka, E. \& Latomaa, S. (2017). Kielitietoisuus eriarvoistumiskehitystä jarruttamassa In N. Lilja, E. Luukka \& S. Latomaa (Eds.), Kielitietoisuus eriarvoistuvassa yhteiskunnassa [Language Awareness in an Increasingly Unjust Society]. AFinLAn vuosikirja 2017, 11-29. Retrieved on 15th December 2017 from: https://journal.fi/afinlavk/issue/view/4674

Lucas, T. \& Villegas, A. M (2011). A framework for preparing linguistically responsive teachers. In Lucas, T. (Ed), Teacher Preparation for Linguistically Diverse Classrooms: A Resource for Teacher Educators (pp. 55-72). NY: Routledge.

Lucas, T. \& Villegas, A.M. (2013). Preparing Linguistically Responsive Teachers: Laying the Foundation in Preservice Teacher Education, Theory Into Practice, 52(2), 98-109.

MacSwan, J. (2017). A multilingual perspective on translanguaging. American Educational Research Journal, 54(1), 167-201. DOI: 10.3102/0002831216683935. 2017 AERA. http://aerj.aera.net

May, S. (2013). Introducing the "Multilingual Turn". In S. May (Ed.), The Multilingual Turn: Implications for SLA, TESOL and bilingual education (pp. 1-6 ). London: Routledge.

Mehmedbegovic, D. \& Bak, T. (2017). Towards an interdisciplinary lifetime approach to multilingualism: From implicit assumptions to current evidence. European Journal of Language Policy, 9(2), 1-19. DOI: 10.3828/ejlp. 2017.10

Menken, K. \& Kleyn, T. (2010). The long-term impact of subtractive schooling in educational experiences of secondary English language learners. International Journal of Bilingual Education and Bilingualism 13(4), 399-417. doi.org/10.1080/13670050903370143

Milbourn, T., Viesca, K. M., \& Leech, N. (2017). Measuring linguistically responsive teaching: First results. American Educational Research Association annual meeting, 2017. San Antonio.

National Agency of Education (2014). Perusopetuksen opetussuunnitelman perusteet [Finnish Core Curriculum for Basic Education]. Määräykset ja ohjeet 2014:96. Retrieved on 23rd March 2017 from: 
http://www.oph.fi/download/163777_perusopetuksen_opetussuunnitelman_perusteet_2014. pdf

National Agency of Education (2015). Lukion opetussuunnitelman perusteet. [Finnish Core Curriculum for Upper Secondary Education]. Määräykset ja ohjeet 2015:48. Retrieved on 23rd March 2017 from:

http://www.oph.fi/download/172124_lukion_opetussuunnitelman_perusteet_2015.pdf

National Agency of Education (2017). Vieraskieliset perusopetuksessa ja toisen asteen koulutuksessa 2010-luvulla. Elever och studerande med ett främmande språk som modersmål på 2010-talet. M. Portin (Ed.), Raportit ja selvitykset 2017:10. Opetushallitus. http://oph.fi/julkaisut/2017/vieraskieliset_perusopetuksessa_ja_toisen_asteen_koulutuksessa _2010-luvulla

Ovando, C. J. \& Combs, M. C. (2011). Bilingual and ESL Classroom: Teaching in Multicultural Contexts. 5th edition. New York: McGraw-Hill Education.

Paris, D. (2012). Culturally Sustaining Pedagogy: A Needed Change in Stance, Terminology, and Practice. Educational Researcher, 41 (3), 93-97. DOI: 10.3102/0013189X12441244

Pyykkö, R. (2017). Monikielisyys vahvuudeksi. Selvitys Suomen kielivarannon tilasta ja tasosta. [Multilingualism into a strength. A report of the status and levels of language competences in Finland]. Opetus- ja kulttuuriministeriön julkaisuja 2017:51. [Publications of the Ministry of Education and Culture, Finland 2017:51]. Retrieved on 10 2018 January from: http://julkaisut.valtioneuvosto.fi/bitstream/handle/10024/160374/okm51.pdf

Richards, J. C., Tung, P., \& Ng, P. (1992). The culture of the English language teacher: A Hong Kong example. RELC Journal, 23, 81-102.

Skutnabb-Kangas, T. (2008). Human rights and language policy in education. In S. May \& N. H. Hornberger (Eds.), Encyclopedia of language and education ( $2^{\text {nd }}$ edition, Vol. 1) (pp. 107119). New York: Springer.

Skutnabb-Kangas, T. (2017). Language Rights. In In W. E. Wright, S. Boun \& O. García (Eds.). The Handbook of Bilingual and Multilingual Education (pp. 185-202). Oxford: Wiley.

Skutnabb-Kangas, T. \& Dunbar, R. (2010). Indigeneous children's education as linguistic genocide and a crime against humanity? A global view. Gáldu Cála. Journal of Indigeneous People’s rights, $1 / 2010$.

Slavin, R. \& Cheung, A. (2005). A synthesis of research on language of reading instruction for English Language Learners. Review of Educational Research, 75, 247-281.

Statistics of Finland (2016). Ulkomaalaistaustaiset [People with Foreign background]. Retrieved on $3^{\text {rd }}$ December 2017 from: https://www.stat.fi/tup/maahanmuutto/maahanmuuttajatvaestossa/ulkomaalaistaustaiset.html 
Tarnanen, M., Kauppinen, M. \& Ylämäki, (2017). Oman äidinkielen tekstitaidot monikielisyyttä rakentamassa - näkökulmia kielille annettuihin merkityksiin ja kielten käyttöön In N. Lilja, E. Luukka \& S. Latomaa (Eds.) Kielitietoisuus eriarvoistuvassa yhteiskunnassa [Language Awareness in an Increasingly Unjust Society]. AFinLAn Vuosikirja 75, 278-297. Retrieved on 15th December 2017 from: https://journal.fi/afinlavk/article/view/60559

Taylor, L. K., Bernhard, J. K., Garg, S. \& Cummins, J. (2008). Affirming plural belonging: Building on students' family-based cultural and linguistic capital through multiliteracies pedagogy. Journal of Early Childhood Education, 8(3), 269-294. DOI: $10.1177 / 1468798408096481$

Thomas, W. P. \& Collier, V. P. (2002). A national study of school effectiveness for language minority students' long-term academic achievement. Santa Cruz, CA: Center for Research on Education, Diversity and Excellence, University of California-Santa Cruz. Retrieved on $16^{\text {th }}$ November 2017 from: www.crede.ucsc.edu

Valdiviezo \& Nieto, S. (2017). Culture in Bilingual and Multilingual Education. Conflict, Struggle, and Power. In W. E. Wright, S. Boun \& O. García (Eds.), The Handbook of Bilingual and Multilingual Education (pp. 92-108). Oxford: Wiley.

Voet, M. \& DeWever, B. (2016). History teachers' conceptions of inquiry-based learning, beliefs about the nature of history, and their relation to the classroom context. Teaching and Teacher Education, 55(1), 57-67. DOI: 10.1016/j.tate.2015.12.008

X. X. \& Author 4 (2011).

Zilliacus, H., Holm, G. \& Sahlström, F. (2017). Taking steps towards institutionalising multicultural education - The national curriculum of Finland, Multicultural Education Review, 9(4), 231-248. DOI: 10.1080/2005615X.2017.1383810 